\title{
NON-DISClOSURE: SOME COMPARISONS
}

\author{
Paul Walker
}

The question of disclosure, what is and what is not required to be disclosed when a contract is created, has long been a vexed problem in insurance law. This article considers recent developments in the law on this question and notes the possibility of the development of the further development of a proportionality approach.

\section{INTRODUCTION}

In their excellent recent book, ${ }^{1}$ Anthony Duggan, Michael Bryan and Frances Hanks remind us that the law and morality of non-disclosure were discussed by Cicero ${ }^{2}$ over 2000 years ago. Cicero takes some hypothetical facts which are the subject of an imaginary dialogue between two philosophers. A grain merchant is on board his ship carrying a cargo of corn from Alexandria to Rhodes at a time of famine. In the course of the voyage, the merchant overtakes other vessels taking corn to Rhodes. On arrival at Rhodes, is the merchant under a duty to tell the Rhodians about the other ships, or may he remain silent and sell his cargo at the famine price? Diogenes says that a merchant is not obliged to disclose everything that it would be useful for a buyer to know: provided he remains truthful, the merchant may remain silent. The famous phrase which Cicero attributes to him is that "concealing is one thing, not revealing is another" (aliud est celare, aliud tacere). By contrast, his pupil Antipater says that a duty exists to reveal the information. He says this duty arises from the bond of community that links every person in the world to each other. Cicero agrees with Antipater, and asserts that Antipater's moral position represents Roman law.

* Senior Lecturer in Law, Victoria University of Wellington.

1 Contractual Non-Disclosure (Longman Professional, Melbourne, 1994).

2 In his treatise on duties, De Officiis. 
As is well known, by the early 19th century English ${ }^{3}$ and American ${ }^{4}$ cases on the general law of contract had plumped for Diogenes. In the general law of contract, there must be something exceptional about the conduct of the non-discloser before the court will intervene. ${ }^{5}$ But there is one field of contract law where this is not the case: insurance. "The insurance contract is the sole remaining survivor in common law systems of that special category of transactions known as the 'contract of the utmost good faith', and the obligation to disclose derives from the nature of that contract."6

In this article I shall give an outline (necessarily selective) of how some aspects of the duty of disclosure in insurance contracts have fared in four common law jurisdictions (America, England, Australia, and New Zealand).

\section{AMERICA}

The law of the United States of America of course is not unitary. The insurance law of the USA comprises the laws of 50 states and a Federal District. Every state has its own insurance code which may codify the rule of disclosure. Nevertheless it is possible to make some reasonably accurate generalisations.

A first generalisation is that American law distinguishes marine and non-marine risks. In the case of marine risks, American courts have adopted a doctrine which appears similar to that of other common law jurisdictions. Couch defines the doctrine in this way: ${ }^{7}$

Concealment in marine insurance is the failure to disclose any material fact or circumstance in relation to the subject matter of the contract which may increase the liability to loss, or affect the risk or obligation assumed, and which is, in fact or law, within, or which ought to be within, the knowledge of one party, and of which the other party has not actual or presumptive knowledge.

3 Fox $v$ Makreth (1788) 2 Cox Eq Cas 320.

4 Laidlaw $v$ Organ 15 US (2 Wheat) 178 (1817).

5 Duggan et al, above n 1, 12-13, give four main categories: (1) knowledge by the non-discloser of a mistake by the other party; (2) active concealment (amounting to misrepresentation) by the non-discloser; (3) knowledge by the non-discloser of a disability affecting the other party's party capacity for informed consent; (4) abuse by the non-discloser of a position of trust.

6 Duggan et al, above n 1, 13. At 79ff the authors discuss the limited disclosure obligation in contracts of guarantee (as to which, see now Westpac Banking Corporation $v$ Robinson (1993) 30 NSWLR 668, noted by Murdoch (1995) 8 JCL 286); and Levitt v Barclays Bank [1995] 1 WLR 1260.

7 Couch, Cyclopedia of Insurance Law (2ed, Lawyers Co-operative Publishing Co, New York, 1985) vol 9, § 38.75. In contrast to Cicero, Couch appears to use "concealment" to mean "actionable non-disclosure". 
But in relation to non-marine insurance American jurisprudence is not so strict. In this context it has been stated that: ${ }^{8}$

... concealment exists and avoids the policy where the insured has knowledge of a fact material to the risk which honesty, good faith, and fair dealing require that he should communicate to the insurer but which he designedly and intentionally withholds.

Francis Achampong, writing in 1987, observed ${ }^{9}$ that the rationale for the stricter rule for non-disclosure in marine insurance was the difficulty of predicting the perils which an ocean-going vessel might encounter, and the impracticality of using specific questionnaires. He also drew attention ${ }^{10}$ to a suggestion that this stricter rule was applied in other areas of insurance where the insured had greater knowledge of the risks involved (such as title insurance). Achampong's conclusion was that the relatively equal bargaining power and business acumen of the parties relieved any pressures for change of the law in relation to marine insurance. He recognised that a constant adjustment to changing circumstances was required in order to fashion the distinctions and exceptions in the United States, but considered that the courts in that country had taken cognisance of present realities, changed circumstances and the difference between marine and non-marine underwriting. In his view the satisfactory state of the American position was a tribute to judicial activism. ${ }^{11}$

The most recent developments in America are described in an article ${ }^{12}$ by Deborah $\mathrm{F}$ Cohen, Timothy E DeMasi, and Aaron Krauss. They report that while the Fifth Circuit of the US Court of Appeals has moved ${ }^{13}$ towards a less strict rule in marine insurance (equating the position with the rules as to non-disclosure applicable in non-marine insurance), this move has been repudiated by the Federal Court for the Southern District of the State of New York (which forms part of the Second Circuit). ${ }^{14}$ Further, recent decisions in the United States have asserted that the stricter rule of disclosure is applicable to contracts of reinsurance, even where the reinsurance is non-marine in nature. ${ }^{15}$

8 Above $\mathrm{n} 7, \S 38.2$.

9 "Uberrima Fides in Insurance Law" (1987) 36 ICLQ 329, 339.

10 Above n 9, 339, footnote 45, citing Gerace and Sandow, “Uberrimae Fidei and Al-Risk Policies: Revival of a Historic Defense" (1986) Insurance Counsel Journal, January, 154, 156.

11 Achampong, above n 9, 345-347.

12 “Uberrimae Fidei and Reinsurance Rescission: Does a Gentlemen's Agreement have a Place in Today's Commercial Market?" (1994) 29 Tort \& Ins LJ 602.

13 In Albany Ins Co v Anh Thi Kieu 927 F 2d 882 (5th Cir), cert denied, 112 S Ct 279 (1991).

14 See Employers Ins $v$ Triton Lines Inc No 88 Civ 5276, 1991 WL 190592 (SDNY Sept 18, 1991).

15 Cohen et al, above n 12, citing Security Mutual Casualty Co v Affiliated FM Insurance Co 471 F 2d 238, 241 (8th Cir 1972), Carlingford Australia General Insurance Ltd $v$ St Paul Fire \& Marine Insurance Co 722 F Supp 48 


\section{ENGLAND}

When examining the law of non-disclosure in England it is vitally important to distinguish between the law and the practice of insurance. I deal first with the law and second with the practice.

\section{A The Law}

The Marine Insurance Act 1906 provides by ss 17 and 18:

17. Insurance is uberrimae fidei

A contract of marine insurance is a contract based on the utmost good faith, and, if the utmost good faith be not observed by either party, the contract may be avoided by the other party.

18. Disclosure by assured

(1) Subject to the provisions of this section, the assured must disclose to the insurer, before the contract is concluded, every material circumstance known to the assured, and the assured is deemed to know every circumstance which, in the ordinary course of business, ought to be known by him. If the assured fails to make such disclosure, the insurer may avoid the contract.

(2) Every circumstance is material which would influence the judgment of a prudent insurer in fixing the premium or determining whether he will take the risk.

(3) In the absence of inquiry the following circumstances need not be disclosed, namely:

(a) Any circumstance which diminishes the risk:

(b) Any circumstance known or presumed to be known to the insurer. The insurer is presumed to know matters of common notoriety or knowledge, and matters which an insurer in the ordinary course of his business, as such, ought to know:

(c) Any circumstance as to which information is waived by the insurer:

(d) Any circumstance which it is superfluous to disclose by reason of any express or implied warranty.

(SDNY 1989), Sumitomo Marine \& Fire Insurance Co $v$ Cologne Reinsurance Co 552 NE 2d 139 (NY 1989), and Christiania General Insurance Corp $v$ Great American Insurance Co 745 F Supp 150 (SDNY 1990). 
(4) Whether any particular circumstance, which is not disclosed, is material or not is, in each case, a question of fact.

(5) The term "circumstance" includes any communication made to, or information received by, the assured.

In the most recent English non-disclosure case to reach the House of Lords, Pan Atlantic Insurance Co Ltd $v$ Pine Top Insurance Co Ltd, ${ }^{16}$ it was observed by Lord Mustill ${ }^{17}$ that in relevant respects the common law relating to marine and non-marine insurance is the same, and the Act embodies a partial codification of the common law.

Thus the strict rule applied in the United States to marine insurance (and relaxed in most cases of non-marine insurance) is applied by English law with much the same rigour whether the insurance in question be marine or non-marine. There is a respect in which it appears that the two may differ in English law: this is the question whether the assured need disclose those things which the assured does not know but ought to know in the ordinary course of business. Section 18 plainly requires such disclosure if the risk is marine. It is not entirely clear that such a requirement is imposed by the common law in cases of non-marine insurance. ${ }^{18}$ The point was presumably not mentioned by Lord Mustill in Pan Atlantic because it did not arise in that case.

In his speech ${ }^{19}$ in Pan Atlantic Lord Mustill listed criticisms which had been made of English law as it then stood, and dealt with them in two groups. The first group was of criticisms which (he said) the House of Lords in its judicial capacity was powerless to remedy. Among them were the following:

(i) The law deprives the assured of a recovery for a genuine loss by perils insured against even if the misrepresentation or non-disclosure had no bearing on the risk which brought about the loss.

(ii) The law deprives the assured of the whole of his recovery even if a full and accurate disclosure would have done no more than cause the underwriter to insist on one rate of premium rather than another.

16 [1995] 1 AC 501.

17 Above n 16, 518.

18 Ivamy General Principles of Insurance Law (6 ed, Butterworths, London, 1993) 140; and Clarke Law of Insurance Contracts (2 ed, Lloyd's, London, 1994) 579-582 equate marine and non-marine; by contrast the editors of McGillivray Insurance Law (8 ed, Sweet and Maxwell, London, 1988) say McNair J left the question open in Australia and New Zealand Bank $v$ Colonial Wharves [1960] 2 Lloyd's Rep 241. 
(iii) The law fails to take account of whether a reasonable person seeking insurance would appreciate that a particular circumstance was material and ought to be disclosed.

The criticisms which the House of Lords was able to consider included:

(i) The law ought to be that a circumstance is material only if its disclosure would decisively have influenced the mind of the prudent underwriter (a criticism rejected by the majority of their Lordships).

(ii) A defence of misrepresentation or non-disclosure could succeed even if the actual underwriter's mind was unaffected is contrary to common sense and justice (a criticism accepted by all their Lordships, and remedied in their speeches).

Commentators ${ }^{20}$ on Pan Atlantic expressed concern that the requirement of actual inducement would mean little in practice, for (as Lord Mustill himself pointed out) once the materiality of the undisclosed fact was established, there may be a presumption that nondisclosure induced the contract. In the words of Clive Boxer: ${ }^{21}$

Little has really changed. It is still all or nothing; it is still the views of a prudent independent underwriter that count for materiality; and unless the underwriter makes a complete fool of himself in the witness box there will be a presumption of inducement in his favour.

Subsequent cases have done little to allay this concern.

In March 1995, Longmore J delivered judgment in Marc Rich \& Co AG v Portman. ${ }^{22}$ The case concerned a charterers' liability policy, extended by endorsements to include liability for delay at the ports of Ain Sukhna and Constanza. At issue was whether past experience should have been disclosed by the insured charterer, and would have made a difference to the underwriter's decision. The judge's findings after evidence had been given by the underwriter who scratched the slip for the endorsements (Mr Overton) might be described as devastating: ${ }^{23}$

He knew virtually nothing about the sort of liabilities likely to be incurred by charterers of ships; he had never seen a charterparty, could not define demurrage and had no concept of laytime or notices of readiness. He had no idea what the Asba 2 form was and did not know

20 Eg Hamilton "Development in the duty of disclosure" (1994) 144 NLJ 1313; Birds and Hird "Misrepresentation and Non-disclosure in Insurance Law - Identical Twins or Separate Issues?" (1996) 59 MLR 285; Boxer "Pine Top emerges above Atlantic" (1994) 138 Sol Jo 936.

Boxer, above n 20, 937. 
how to find a copy. He had no idea whether liabilities incurred by charterers were capable of being passed on to any third parties; he had no idea of any loss experience of Marc Rich relevant to the endorsements.

When dealing with such an obviously incompetent underwriter the circumstances might seem propitious for a submission that the underwriter would not have been induced to do anything different had charterer's experience been disclosed. But appearances were deceptive. When rejecting the submission, Longmore J made some interesting observations about the relevance of what had been done by the underwriter on other occasions: ${ }^{24}$

Mr Overton was naturally pressed by Mr Kealey to admit that, since he regarded the extension of the risk set out in the endorsement as so very minor, it would have made no difference to him if he had been shown a document recording that there were substantial, but ex hypothesi irrelevant, demurrage liabilities which had been incurred previously by Marc Rich at the relevant ports. Mr Overton's answer was:

"If I was shown a record with that information on it, the question I am sure I would have asked is: We are definitely not covering these instances.... I would have just confirmed, sighting our records, that we were not covering those".

Mr Kealey submitted that I should not accept that answer since it was obviously self-serving and inconsistent with the true picture of a man who had abrogated his underwriting functions and existed in an intellectual "stupor."

A submission of this kind has to my mind, to be tested against the overall conduct of $\mathrm{Mr}$ Overton in relation to the Marc Rich risk. Mr Saloman, indeed, submitted that I could not reach such a conclusion by looking at only 2 or 3 underwritings and that it would be necessary to look at Mr Overton's writings for a number of years. This turned out to be a peculiarly unattractive submission when it emerged that insurers had been asked to disclose $\mathrm{Mr}$ Overton's writings over a period of 5 years and that they had declined to do so.

It would, however, be a most unfortunate consequence of the House of Lords' decision in Pan Atlantic $v$ Pine Top if cases of this kind were to be saturated with inquiries about a plethora of risks written by the actual underwriter on occasions other than the time when the relevant risk was itself written. In my view the question whether the actual underwriter was induced to write the relevant risk is to be determined by reference to the actual risks underwritten and their immediate context. The question in this case is then whether the underwriter abrogated his functions in relation to these risks not in relation to numerous other risks written on different occasions cf Merchant Insurance Co v Davie [1937] 2 All ER 767.

24 Above n 22, 440-441. 
unlikely that the law will be changed in this advantageous way in the foreseeable future ...However, my Terms of Reference require me to reach a decision which I consider in all the circumstances would be a fair and reasonable resolution of the dispute. ... if the circumstances are such that I could conclude, on a balance of probabilities, that any nondisclosure was innocent I would not allow the insurer to avoid the policy but would require it to adopt the proportionality principle.

Thus in cases of private insurance taken out by UK policyholders avoidance for nondisclosure is only available where the insured could reasonably be expected to have disclosed the matter in question, and even in such a case the Ombudsman will (absent sufficient evidence of fraud) allow the insured a proportionate recovery where the risk would have been written following disclosure at a higher premium. ${ }^{32}$

\section{AUSTRALIA}

Australia, like America, is not a unitary state, but its Constitution gives the Federal Parliament law-making power in relation to insurance. ${ }^{33}$ This enabled the Federal Parliament to bring about major reform of insurance law by enacting the Insurance Contracts Act 1984. The Act is based upon a report of the Australian Law Reform Commission. ${ }^{34}$

Section 21(1) of the 1984 Act provides:

Subject to this Act, an insured has a duty to disclose to the insurer, before the relevant contract of insurance is entered into, every matter that is known to the insured, being a matter that -

(a) the insured knows to be a matter relevant to the decision of the insurer whether to accept the risk and, if so, on what terms; or

(b) a reasonable person in the circumstances could be expected to know to be a matter so relevant.

32 The Ombudsman's proportionality approach also meant that he would permit an insured full recovery if the risk would have been written in any event, a result which coincides with the law after the House of Lords decision in Pan Atlantic.

33 Commonwealth of Australia Constitution Act 1900, s 51 (xiv); there is an exclusion in respect of State insurance, but the individual State insurers have been subjected to relevant Commonwealth legislation (either by agreement or by State legislation).

34 Australian Law Reform Commission Insurance Law Report No 20 (1982). 
Thus the 1984 Act in this regard alters the common law's insurer oriented perspective and adopts a position which is in most respects similar to that of the UK General Statements. ${ }^{35}$

There has been some controversy about the subjectiveness of the test in s21, both in relation to "the insurer" in s21(1)(a) and in relation to the meaning of "in the circumstances" in $\mathrm{s} 21(1)(b)$.

First, the obligation arises in relation to matters "relevant to the decision of the insurer" - but does this mean the actual insurer or a hypothetical prudent insurer? Rogers $\mathrm{CJ}$ held in Ayoub $v$ Lombard Insurance Co (Aust) Pty Ltd ${ }^{36}$ that the common law test was to be applied so that what was relevant was to be determined having regard to a prudent insurer acting reasonably. By contrast in Twenty-first Maylux Pty Ltd v Mercantile Mutual Insurance (Australia) $L t d^{37}$ Brooking J preferred an approach by reference to the concerns of the particular individual insurer. The latter approach seems more consistent with the words of the statute..$^{38}$

Secondly, and perhaps more importantly in practice, the question arises as to how broadly or narrowly one should look at the particular case when asking whether "a reasonable person in the circumstances could be expected to know" that the matter was relevant. This question also arose in the Twenty-first Maylux case: here Brooker J thought that the test did not take into account personal idiosyncrasies of the insured such as imperfect understanding of English. In Western Australia Judge Keall took a different view: ${ }^{39}$ he posited "a reasonable person with the state of knowledge and having the educational background of" the insured. These extreme positions have the potential to operate harshly on insured and insurer; a better approach might be to take the view that "in the circumstances" means "in the circumstances known to both parties."

The 1984 Act also makes specific provision for remedies. Section 28(1) establishes inducement of the insurer as a pre-requisite to remedy for non-disclosure or

35 Note that under s 21, only those matters which are in fact known to the insured constitute candidates for disclosure; cf the UK Statements which seem to leave this open by precluding avoidance by reference to facts "which the policyholder could not reasonably be expected to have disclosed."

36 (1989) 5 ANZ Ins Cas 60-933 (NSW Supreme Court), adopting obiter remarks of Samuels JA in Toikan International Insurance Broking Pty Ltd v Plasteel Windows Australia Pty Ltḋ (1989) 5 ANZ Ins Cas 60-903.

37 (1990) 6 ANZ Ins Cas 60-954 (Supreme Court of Victoria).

38 The editors of the ANZ Insurance Reporter suggest (II 6-020, p 10,967) that the difference may not matter, because the duty of good faith prevents the insurer from acting capriciously or without foundation in making a determination as to whether a particular matter is relevant or not.

39 In Delphin v Lumley General Insurance Ltd (1989) 5 ANZ Ins Cas 60-941, appeal dismissed without comment on this point (1990) 6 ANZ Ins Cas 60-986. 
misrepresentation. Section 28(2) permits avoidance in cases of fraud (but subject to a discretion given to the court by s31). By s28(3), in cases where avoidance is not permitted or is eschewed:

... the liability of the insurer in respect of a claim is reduced to the amount that would place him in a position in which he would have been if the failure [to disclose] had not occurred or the misrepresentation had not been made.

This is an approach which at first sight seems similar to the "proportionality" approach advocated by Nicholls V-C and adopted by the UK Ombudsman. But it is based on a different principle. Take a case where the risk would have been written at a higher premium. Once it is ascertained that the insurer would have written the risk, ${ }^{40}$ albeit on different terms as to premium, the court is to set off the additional premium which would have been charged against the claim.

The 1984 Act is not applicable to certain contracts and proposed contracts. ${ }^{41}$ Among the excluded contracts are those of reinsurance, those to which the Marine Insurance Act applies, and those concerning aircraft engaged in commercial operations. Other exclusions involve registered health benefits, friendly societies, workers compensation and motor insurance (death and personal injuries). The result is that there are numerous regimes of non-disclosure, and this can no doubt cause anomalies. To some extent these have been dealt with by the insurance industry: for example, under a Code of Practice pleasure craft are assumed by the insurance industry to be within the 1984 Act. $^{42}$

\section{NEW ZEALAND}

The law of non-disclosure in New Zealand is reviewed elsewhere in this publication by Malcolm Shelton-Agar and Helen Cruse. ${ }^{43}$ As they observe:

(i) There has been a suggestion from Sir Robin Cooke $e^{44}$ that a full court of five judges might overturn the common law prudent insurer test of materiality in favour of a focus on the reasonable insured.

40 Australian courts have generally rejected a suggestion by Deane $\mathrm{J}$ in Advance (NSW) Insurance Agencies $v$ Matthews (1989) 5 ANZ Ins Cas 60-910 that because one could not reduce an amount to nil, one had to assume that the insurer had written the contract: see ANZ Insurance Reporter II 6-030, 10,984 to 10,991.

41 See $\mathbf{9} 9$.

42 Derek Luxford of Phillips Fox in Sydney has suggested that the industry had misunderstood the law in this respect: see $\mathrm{p} 34$ of The Marine Insurance Act: Chronologically challenged legislation? (a paper delivered at the November 1995 conference held in Wellington by the Maritime Law Association of Australia and New Zealand).

43 In "Nefarious Activities: to disclose or not to disclose."

44 In State Insurance v McHale [1992] 2 NZLR 399, 405. 
(ii) The Court of Appeal in Gate $v$ Sun Alliance 45 suggested that good faith required insurers to signal that fair and accurate answers to questions might not discharge an insured's obligations.

Perhaps as a result of these indications, the Fair Insurance Code adopted by the Insurance Council of New Zealand requires members, at the time of a customer's taking out or renewing insurance, to "advise customers of their duty to tell the insurance company of all facts which will affect the insurance company's assessment of the risk in providing insurance cover."

Statutory reform of the law of contract in general and of the law of insurance in particular was a consistent feature of New Zealand legislation in 1970s and 1980s. But non-disclosure is not specifically dealt with in these reforms. Craig Brown has pointed out ${ }^{46}$ that shortly before its abolition the Contracts and Commercial Law Reform Committee indicated that it would return to the question of non-disclosure at a later date, ${ }^{47}$ while the Law Commission, with its more general focus, has not yet turned its attention to the topic. It is nevertheless important to bear in mind that more general statutes may have an important practical effect where there has been non-disclosure. Among these are:

(i) The provisions as to the supply of services in the Consumer Guarantees Act 1993. The definition of "service" contained in s2 expressly extends to a contract of insurance (including life assurance and life reassurance). I have suggested on other occasions ${ }^{48}$ that this may have a considerable impact. In particular, by s29, unless the consumer ${ }^{49}$ does not rely (or unreasonably relies) on the insurer's skill or judgment, there is a guarantee that the insurance will be:-

(a) Reasonably fit for any particular purpose; and

(b) Of such a nature and quality that it can reasonably be expected to achieve any particular result that the [insured] makes known to the [insurer], before or at the time of the making of the contract [of insurance], as the particular

45 Unreported, 5 April 1995, Court of Appeal, CA 37/94.

46 In "Unfinished business: Misrepresentation and Non-disclosure in Insurance Proposals" (1994) 16 NZULR $195,196$.

47 Contracts and Commercial Law Reform Committee Aspects of Insurance Law (2) (Wellington, 1983 ) 40.

48 In an address to the NZ Insurance Law Association, August 1994, and at a VUW Law Faculty and Wellington District Law Society Seminar, 6 September 1994.

49 Defined in $\mathrm{s} 2$ in such a way as to include those acquiring insurance for personal, domestic or household use or consumption. 
purpose for which the service is required or the result that the consumer desires to achieve, as the case may be ...

Is, for example, motor vehicle insurance reasonably fit for its purpose if it can be avoided for failure to disclose something which the insured did not know but ought in the ordinary course of business to have known? Or if the fact not disclosed was material but a reasonable insured (as opposed to the prudent underwriter) would not have appreciated this?

(ii) Fair Trading Act 1988: The statute is of mandatory application. It has been held that mere failure to warn of duty of disclosure is not misleading conduct. ${ }^{50}$

(iii) The Contractual Mistakes Act 1977 was applied to an insurance contract in Wijeyaratne $v$ Medical Assurance Society NZ Ltd, ${ }^{51}$ where the insured and insurer both wrongly thought that in the event of damage to a specified vehicle the insured could make a valid claim. This was wrong because the insured had no interest in the vehicle. But it was held to be a common mistake and relief was granted by Hillyer J under the statute. By parity of reasoning, can one say that if an insured and insurer both mistakenly think that all relevant matters have been disclosed, the statute comes into play?

Scope exists in New Zealand for the practice on non-disclosure to differ from the law. Specifically in relation to the question of "proportional" recovery, I have been informed by the Insurance Ombudsman, Terry Weir, that while he is aware of the question, it has not yet arisen in a concrete case. We shall have to wait and see.

50 See the discussion of Gate $v$ Sun Alliance and Quinby $v$ General Accident in Shelton-Agar and Cruse, above $\mathbf{n} 43$.

51 [1991] 2 NZLR 332. 